\title{
THE REGIME SWITCHING OF CYCLE INSTABILITY OF ISLAMIC BANKING AND THE ECONOMY: EVIDENCE FROM INDONESIA, MALAYSIA, AND PAKISTAN
}

\author{
Irfan Nurfalah ${ }^{1}$ and Aam Slamet Rusydiana ${ }^{2}$ \\ ${ }^{1}$ PT Bank BNI Syariah, Indonesia, irfan.nurfalah@gmail.com \\ ${ }^{2}$ Smart Indonesia, Indonesia, aamsmart@gmail.com
}

\begin{abstract}
This study aims to examine the cyclical instability of Islamic banking in Indonesia, Malaysia, and Pakistan. A stable Islamic banking system can give the public confidence to conduct transactions and thus grow the economy. The proxy variable for stability used is the z-score, with 156 periods of research data from January 2007 to December 2019. The Markov Switching Vector Autoregression (MS-VAR) method was employed. The results show that Islamic banking stability in Indonesia based on the z-score is more stable than others. Nevertheless, in terms of the regression of all the variables, regime shifting, and the duration of the crisis, overall Malaysian Islamic banking displays the best performance. The instability of the Indonesian model is mostly affected by inflation, whereas Malaysia and Pakistan are affected by the financing to deposit ratio and the fluctuation in global oil, respectively.
\end{abstract}

Keywords: Cycle instability, Islamic banking, Economy.

JEL classification: E32; G21.

\author{
Article history: \\ Received : October 8, 2020 \\ Revised : March 2, 2021 \\ Accepted : : March 8, 2021 \\ Available online : May 20, 2021 \\ https://doi.org/10.21098/jimf.v7i2.1362
}




\section{INTRODUCTION}

\subsection{Background}

Islamic banking plays a vital role in financial stability as it is is the intermediary institution between debtors and creditors. Moreover, it possesses a considerable proportion of the total assets in all Islamic financial sectors. The Islamic Financial Services Board reported in 2020 that Islamic banking had attained the first position in relation to the composition of the total assets of the Islamic financial industry, at around $72.4 \%$, followed by sukuk at around $22.3 \%$. Islamic fund assets were around $4.2 \%$, with the smallest being takaful, at approximately $1.1 \%$ (IFSB, 2020). The report states that Islamic banking stability has an essential systemic impact on financial stability and overall economic stability. Furthermore, banking stability will be affected by economic indicators such as oil prices, currency fluctuations, unrestrained inflation and interest rates, amongst many others (Lee \& Lee, 2019; Priti, 2016).

Ascarya (2010) summarised that the causes of repeated financial crises and the level of their severity were the result of excess money supply, at $2.8 \%$; interest rates, at $45.2 \%$; and exchange rates, at $18.6 \%$. These indicators are commonly used to indicate crisis triggers. However, many other indicators, such as oil prices, inflation and debt, have a magnitude impact on economic, financial, and banking stability (Lee \& Lee, 2019; Ryu \& Yu, 2020). Malaysia's central bank defines financial system stability as the condition in which the intermediary financial process functions smoothly and exists in financial institutions' operational institutions and trust in the economy market (Central Bank of Malaysia, 2020b). The financial system is declared to be successful or stable if financial institutions' performance is optimal in allocating economic resources and they have stability in facing various internal financial, and external macroeconomic, shocks (Ascarya, 2009). Moreover, Nurfalah, Rusydiana, Laila and Cahyono (2018) explain that economic shocks or crises are economic cycles that continue to change from a stable to an unstable period and vice versa, so the benchmark for determining policy is a variable that affects the crisis and the duration of the problem.

The phenomenon of global economic instability will continue to have a presence in countries in the world. It is caused by many factors, including trade wars, exchange rates, world crude oil prices, and fed rates, amongst many others. US Energy Information Administration data from January 1986 to August 2020 show that world crude oil data fluctuated greatly, along with the data graph (EIA, 2020). 


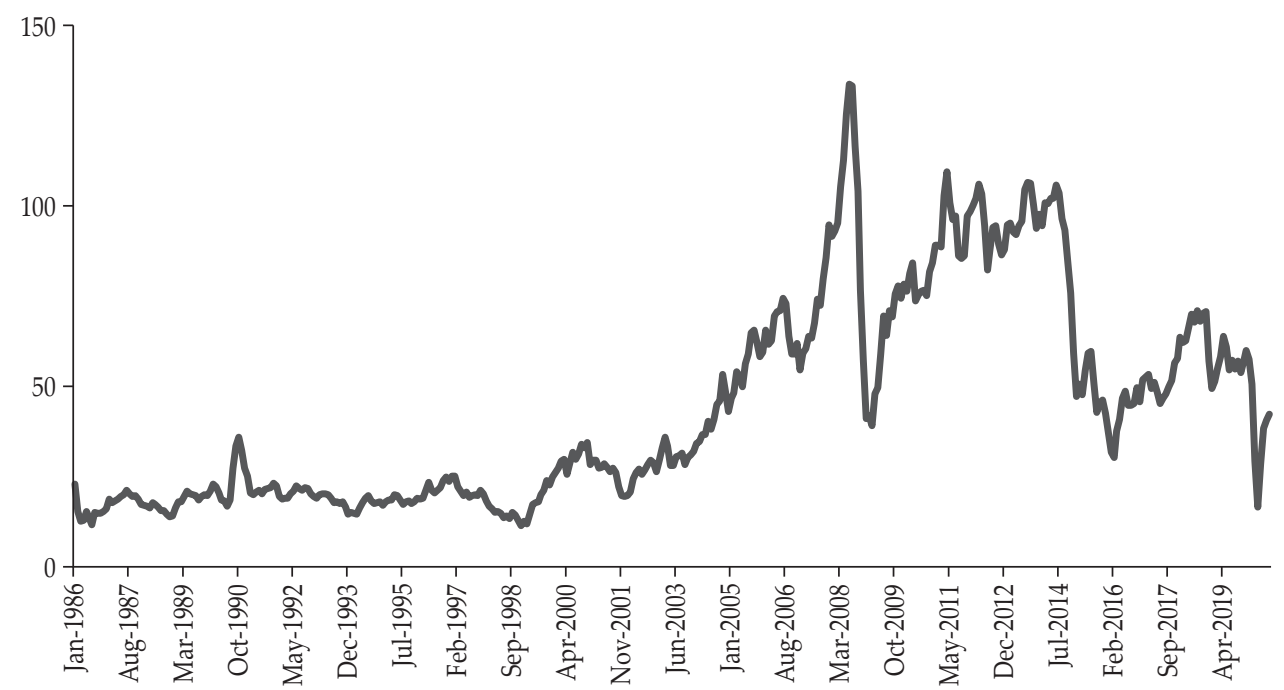

Source: US Energy Information Administration, accessed October 3, 2020

Figure 1.

Crude Oil Prices Jan 1986-Aug 2020

Nizar (2012) analysed the impact of crude oil prices on the Indonesian economy. His results indicate that price volatility negatively impacted the Indonesian exchange rate, raising the internal interest rate, and increasing inflation and excess money supply. On the other hand, Wong and Shamsudin (2017) researched the impact of crude oil prices on Malaysian food price fluctuations. Their results show that prices had a long-term symmetric effect on the country's food price volatility. These studies demonstrate that crude oil prices have a significant impact on rises in the inflation rate and excess money supply. The strategy to stabilise the indicators is to increase interest rates, which will have an impact on non-performing loans, thus raising the liquidity risk for banks, leading to banking crises. Therefore, economic, financial, and banking stability has a mutual spillover effect (Andries \& Galasan, 2020; Agénor \& Pereira, 2014; Mishkin, 2011).

Laeven and Valencia (2012) indicated that the IMF had established that a crisis occurred not only in relation to one element, but that there were often twin or even triple crises. During the period 1997-2011, there were 147 cases of banking crises, 218 cases of currency crises , 66 cases of of government debt crises, 68 cases of twin crises, and eight cases of triple crises.

Reinhart and Rogoff (2013) state that banking crises usually begin with an asset price bubble, high capital income, and a credit boom. Moreover, they found that three years after the crisis, government debt had increased by around $86 \%$, becoming a burden on the fiscal budget as it had to bear the cost of large bailouts. Therefore, banking plays a crucial role in economic and financial cycles.

Unstable economic conditions denoted by a high level of volatility will affect the banking sector in Indonesia, Malaysia, and Pakistan. An exchange rate crisis will disrupt banks' intermediation function, marked by insolvency conditions 
or banks' inability to pay debts on time. The amount of liabilities exceeds assets burdensome to the bank's liability side (Mutiah \& Tamanni, 2010). This will cause dual crises, namely a debt crisis that cannot be paid on time in the medium term. If this situation is not handled quickly, it will result in depleted banking capital reserves, and diminishing public trust, indicated by the large number of people who disburse all their funds, meaning that banking liquidity is ultimately reduced, leading to a banking crisis. This means that if a country's economic conditions are not handled properly when the currency exchange rate sharply depreciates against the US dollar, it is possible to become trapped in a triple crisis (currency, debt, and banking crises), which also applies to Islamic banking (Laeven \& Valencia, 2012).

Several researchers have conducted studies on the regime-switching of cyclical instability of Islamic banking; for example, Nurfalah et al. (2018) and Zahra, Ascarya \& Huda (2018), who analysed the insolvency and instability of Islamic banking in Indonesia using that methodology. However, there remains a lack of research which compares several countries as case studies. Therefore, this study will focus on banking, principally Islamic banking stability, by focusing on three countries: Indonesia, Malaysia, and Pakistan, as examples of Islamic banking in Asia. The selection of these three countries was due to the relatively large number of Islamic banks in them (Financial Services Authority of Indonesia, 2020; Akram Laldin, 2008; Central Bank of Malaysia, 2020a; State Bank of Pakistan, 2020b). This was deemed to be a suitable combination countries for this research. Therefore, it will be interesting to analyse the regime-switching of Islamic banking cycle instability in the three countries.

\subsection{Objectives}

Based on the background described above, the study has several main objectives:

1. To evaluate the cycle of instability in Islamic banking and the economy in Indonesia, Malaysia, and Pakistan;

2. To identify the best level of Islamic banking stability in Indonesia, Malaysia, and Pakistan;

3. To ascertain the indicators that have the most influence on Islamic banking and economic instability in the three countries.

The paper is structured as follows. After the research background in the first part, the second part discusses the background theory of financial system stability with reference to several previous studies. The third part describes the methodology, comprising the data, development models, and methods. The fourth section presents the research results while providing the preliminary test, three observed countries' results, and the analysis and discussion. The fifth part consists of the summary of the main discussion and the recommendations.

\section{LITERATURE REVIEW}

\subsection{Background Theory}

The bank's theory is one of the monetary circuit theories that considers production, capital accumulation, and income distribution, which is fundamentally related to money creation and money circulation in banks. Money creation by banks occurs 
when they lend money to firms and corporations, and utilise the loans for their operational activities. This theory integrates the real sectors of the economy and monetary economies. In addition, it makes a consistent attempt to conceptualise the role of banks, bank credit, and money function in macroeconomics (Bossone, 2001).

Gorton and Winton (2003) state that banks are liquidity providers. They can receive funds from companies with excess liquidity and channel these to others that need liquidity. This is the central role of banks, and it can dominate a decentralised market. Therefore, banks' important role can affect market sensitivity and financial, monetary, and economic stability.

This is a comprehensive explanation of the relationship between financial and monetary stability, which bank is the circulation player (Central Bank of Indonesia, 2020).

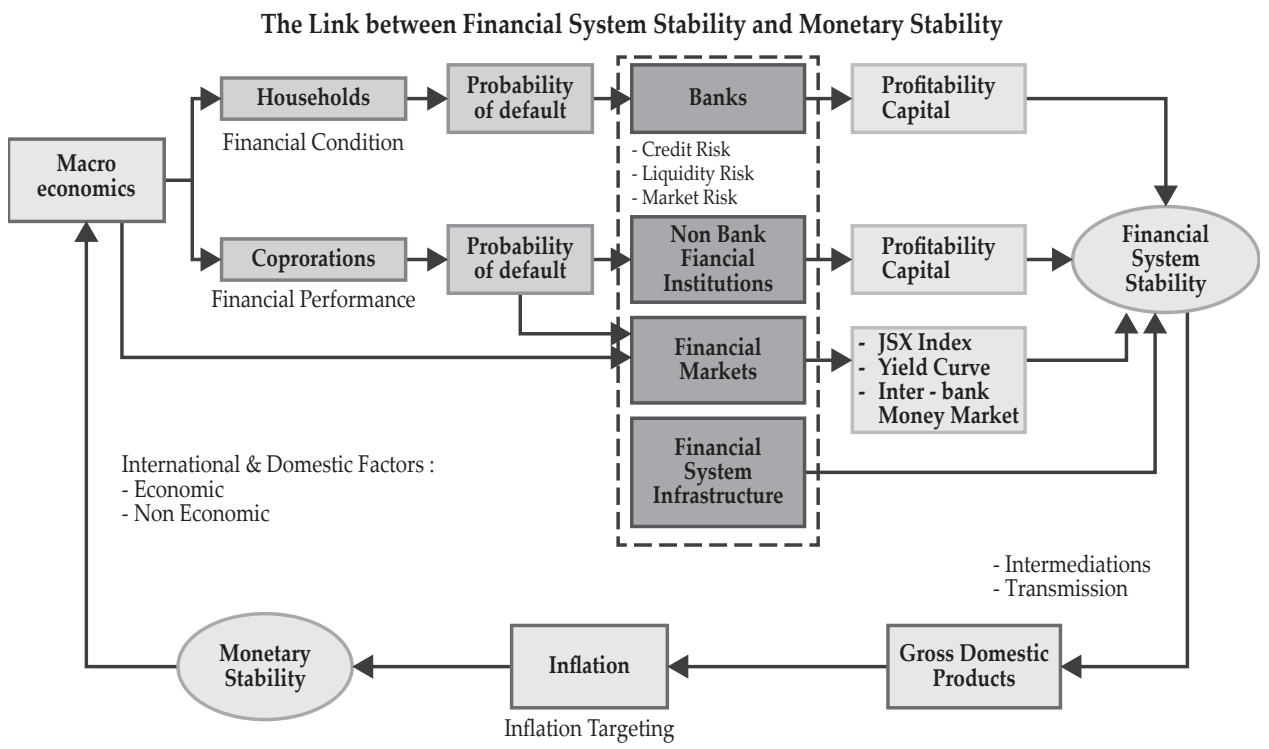

Source: Central Bank of Indonesia. (www.bi.go.id)

Figure 2.

Relationship between Financial System Stability and Monetary Stability

The diagram in Figure 2 illustrates two financial conditions: 1) the household financial condition, and 2) corporate financial performance. Banking supports household finances through its role as an intermediary industry in channeling loans to households. However, the banking industry faces risks that must be continually considered for them to be profitable for creditors and investors who deposit funds into banks; for example, liquidity risk and market risk. If these three risks can be managed properly following macroprudential provisions, this will create financial system stability. However, on the other hand, if the three risks experience disruption, such as a high non-performing loan/financing ratio, 
financial system stability will be disrupted, which may lead to the possibility of instability/crisis.

Furthermore, corporate finance is supported by non-bank financial institutions and financial markets. If corporate performance is good, this will lead to profits, whereas corporate performance tends to be wrong. If the possibility of loss is higher, this will lead to financial system instability. In addition, the performance of corporations listed on the stock exchange will be visible and open globally, so it can be assessed whether the corporation is in good or a bad condition. A bad condition will be reflected in a decline in the price of shares owned. If this happens continuously, the corporation will experience bankruptcy, even leading to systemic risk for other corporations. Therefore, a stable corporate condition with an adequate financial system infrastructure will create financial system stability.

Such stability greatly affects gross domestic product using the intermediation method and the monetary transmission mechanism. One of the transmission objectives is inflation targeting, in which price stability is the main target by adjusting the inflation rate. If the inflation rate is well controlled and goods are affordable, monetary stability will be created. Domestic and international indicators, both economic and non-economic ones, will affect monetary and financial system stability, which are parts of the macroeconomic scope.

Financial system stability differs from monetary stability. The former is more about financial institutions' intermediary role and stability in the financial market. In contrast, monetary stability refers to price stability terms of currency. Financial system stability is difficult to define and measure, so there is no standard definition of it (Schinasi, 2004; Houben, Kakes, \& Schinasi, 2004; Allen \& Wood, 2006). In contrast to monetary stability, price stability and price stability are identical to the inflation rate. The conventional view is that inflation is the main factor that creates financial instability. Another theory is that price stability will improve financial stability, which is based on historical situations where banking crises often occured during recessions after periods of high inflation (Issing, 2003).

The central bank of Pakistan has determined the measurement of financial system stability in four ways: 1) periodic measurement, 2) monitoring of systemic risk, 3) contingency planning anda crisis management framework, and 4) a resolution framework. The measurement of financial system stability is made on an annual basis, with the measurements for Islamic banking being the credit ratio, liquidity ratio, and asset quality. Monitoring of systemic risk is performed by utilising stress testing, employing sensitivity analysis and measured indicators, namely credit, market, and liquidity risk indicators. Contingency planning is the process of preparing for a potential crisis. Successful crisis management can be seen from the limited losses due to the crisis, and if post-crisis recovery can be normalised at minimal costs. A practical resolution framework will ensure a smooth and uninterrupted state financial system, the protection of depositors' funds, the protection of public and taxpayer funds, and ensure that public confidence in the financial system is maintained (State Bank of Pakistan, 2020a).

In addition, the Malaysian central bank established several measurements that must be maintained for the financial system to remain stable, namely the management of household debt, of developments in the domestic property market, of credit risk exposure for businesses, of risks from financial market volatility, and 
of impact risk. Wrong from external exposure and overseas operations (Central Bank of Malaysia, 2020b).

Mirakhor and Krichene (2009) state that the Islamic financial system is based on real products and services for overall economic development and growth, created through zakat, waqf, production, an interest-free approach, and speculative trading instruments, which inherently will be resistant to instability. Furthermore, they explain that the stability of the Islamic financial system will be achieved when there are no more risk-free assets and all financial planning is based on the principle of profit-sharing. All financial assets become contingent claims, and there are no interest-based debt instruments. Real assets also protect all the liabilities that the institution directly owns.

Four factors support the stability of the financial system: 1) a stable macroeconomic environment; 2) well-managed financial institutions; 3) effective supervision of financial institutions; and 4) a safe, reliable, and trusted payment system. If there is a disturbance in one sub-sector, then this will spread to other sub-sectors (Illing \& Liu, 2003).

Cihák (2006) explains that there are several divisions of the objectives that are at the core of achieving financial system stability and other policies, namely 1) macroeconomic aims for stability, growth and development; 2) macroprudential aims for financial stability; 3) macroprudential aims for financial security and health, and 4) other finance aimed at deepening, inclusion and effectiveness. This division of objectives will have an impact on decision and policy making when there is a systemic risk that causes economic instability.

\subsection{Previous Studies}

Several studies on financial system stability have been conducted, including (Ryu \& Yu, 2020); (Lee \& Lee, 2019); (Matey, 2019); (Zahra et al., 2018); (Nurfalah et al., 2018); (Ozili, 2018); (Alqahtani \& Mayes, 2018); (Hassan \& Aliyu, 2018); (İdikut Özpençe, 2017); (Powell, 2017); (Fernández, González \& Suárez, 2016).

Research conducted by Ryu and Yu (2020) investigated the effect of subordinated debt on bank performance with the use of several variables. Their results show that debt harms bank performance; an increase in debt will lead to insolvency risk for banks. In addition, Lee and Lee (2019) examined the effect of oil price shocks on Chinese banking performance. Their results indicate that an increase in oil prices will reduce bank liquidity, earning power, capitalisation, and management efficiency.

Moreover, research conducted by Matey (2019) analysed the financial performance of banks in Ghana. He used z-scores as a proxy for banking stability to avoid the risk of insolvency, and criticised the fact that bank loans have to enforce a threshold by 10 percent for unsecured loans and 25 percent for secured ones.

Zahra et al. (2018) researched the stability of conventional and Islamic banking in Indonesia using two comparison indicators, the Banking Stability Index (BSI) and z-scores. The BSI results show that conventional banking is more stable than its Islamic counterpart, but the z-score results show that Islamic banking is more stable. 
Other research was conducted by Nurfalah et al. (2018), which examined instability (crisis) indicators in the dual financial system. Their study made a comparison of the level of stability between conventional and Islamic banking using z-score indicators. Their results show that Islamic banking has a higher $z$-score value (11.933), which means it is more stable than conventional banking, whose $z$-score value was 11.679 .

Ozili (2018) researched the determinants of banking stability in Africa. His results indicate that the significant African banking stability indicators are banking efficiency, government effectiveness, political stability, corruption control, regulatory control, bank size, and unemployment.

Alqahtani and Mayes (2018) measured 76 banks from the Gulf Cooperation Council (GCC) with stability measurements and accounting-based market. Their results show that a small Islamic banking size would be able to survive a crisis period, but that a large one would not be able to.

Hassan and Aliyu (2018) summarised many types of research about the stability of Islamic banking. They conclude with various suggestions: first, that Islamic banking remains affected by interest rates; second, it is still vulnerable to crises; and third, Islamic banks are labeled cost-inefficiency. Therefore, Islamic banking must be improved operationally and in terms of governance in order to have a broader impact on justice and economic welfare. In other research, İdikut Özpençe (2017) examined the impact of several indicators that affect Turkey's economic growth. His results show that unemployment has a significant and negative effect, while inflation has a positive effect but is not significant.

Powell (2017) calculated bank risk in the ASEAN region but focused on Malaysian banks with variable NPLs, condition distance of default (CDD), and tail risk (TR). The results show that Malaysian banks have a lower risk than the ASEAN region overall. Interestingly smaller banks have a higher risk than large ones during non-crisis periods, but a lower one during crisis periods.

Fernández et al. (2016) analyzed the effect of banking stability on economic volatility. Their study used four indicators as a proxy of banking stability: the z-score, NPL, the standard of the ratio of private credit to GDP, and the ratio of loan-loss provisions to total gross loans. The results show that the higher the level of banking stability, the lower the economic volatility, meaning that volatile economic indicators will affect banking stability. Nurfalah et al. (2018) revealed in their regime switching study that many indicators, such as domestic credit, interest rates, and money supply, influenced either conventional or Islamic banking stability.

\subsection{Conceptual Framework}

As explained in the theory, banks play a vital role in the financial and economic cycle. A report from the IFSB stated that Islamic banking has more than $70 \%$ of assets of the entire financial sector (IFSB, 2020). Therefore, if banks are stable, the financial and economic sectors may also be stable. Conversely, if there is a systemic risk of bank insolvency, this may also cause financial and economic crises (Laeven \& Valencia, 2012). Figure 3 shows the conceptual framework created for this research. 


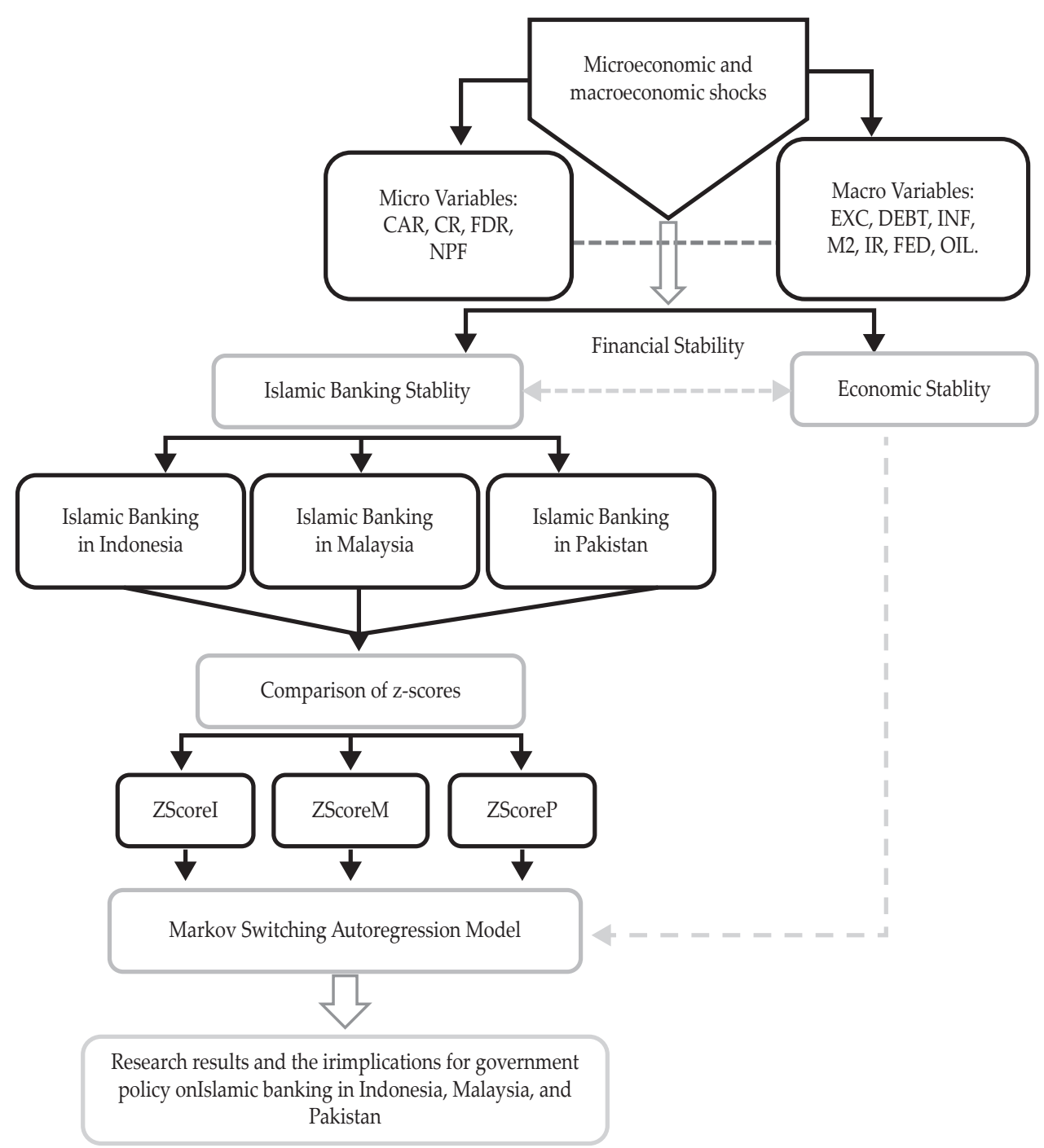

Source: Authors' own elaboration (2020)

Figure 3.

Conceptual Framework

Several internal variables affect the stability and vulnerability of Islamic banking, such as commonly-measured ones based on the previous studies of Bathaluddin, Adhi, and Wibowo (2012), Wagner (2007), and Park, Jun and Lee (2015), namely the capital adequacy ratio, cash ratio, financing to deposit ratio, and non-performing financing. At the same time, it is affected by internal variables and the external variables that significantly impact it. The variables are the exchange rate, debt, inflation, money supply (M2), interest rates, the FED rate, and oil prices. These are taken from various studies, such as those of Ryu and Yu (2020), Tan (2016), Tan and Floros (2012), Helhel (2014), Obeidat et al. (2013), and Khan and 
Sattar (2014). These variables are often used as a measurement of economic and financial stability.

However, the economic cycle combines Islamic banking stability, financial stability, and economic stability. When Islamic banking shock occurs in some variables, it will affect both financial and economic stability fluctuations (Laeven \& Valencia, 2012).

Hence, it is needed to be measured as the indicator of warning that causes Islamic banking instability. According to Čihák and Hesse (2008), the ultimate proxy to measure Islamic banking instability is the z-Score. This study measures the comparison of z-scores from three countries, Indonesia, Malaysia, and Pakistan. Moreover, the methodology used is Markov switching, which has an excellent model on a two-stage regime (Krolzig, 1997). Finally, it can be summarised as the result of this research and obtain government policy implication.

\section{METHODOLOGY}

This chapter will explain the data, methodology, and research model employed. The research methodology includes a description of the econometric model studied and steps related to the research model. Furthermore, the model describes the types and sources of data explored, gives an explanation of the microeconomic and macroeconomic variables used, and the form of the model arranged as an equation model. The methodology used was the Markov switching approach, which uses latent variables that follow the first derivative of two-stage Markov, namely $\left\{S_{t}\right\}_{t=1}^{T}$. St $=1$ is a crisis state, and $S_{t}=0$ is a tranquil state.

The study includes three models: the Indonesian Islamic banking model, the Malaysian Islamic banking model, and the Pakistani Islamic banking model. The model division is intended to observe the level of stability of Islamic banking in each country.

\subsection{Data}

The research period was between January 2004 and December 2019, with secondary data obtained from many sources. The Indonesian Islamic banking data were obtained from Indonesian Banking Statistics, the Financial Services Authority (SPI-OJK), the Islamic Banking Statistics of the Financial Services Authority (SPSOJK), the Central Bureau of Statistics (BPS), Indonesian Economic and Monetary Statistics, Bank Indonesia (SEKI-BI) and the International Financial Statistics (IFS) published by the IMF. The Malaysian Islamic banking data were obtained from the Central Bank of Malaysia (BNM), while the Pakistani Islamic banking data were obtained from the State Bank of Pakistan (SBP). In addition, world crude oil price data were obtained from the US Energy Administration Information, and fed interest rate data were sourced from the IMF and World Bank. Thirteen variables were used in the study, namely the z-score (stability indicator), capital adequacy ratio $(\mathrm{CAR})$, current ratio $(\mathrm{CR})$, non-performing financing $(\mathrm{NPF})$, financing to deposit ratio (FDR), exchange rate (EXC), debt, inflation (INF), interest rate (IR), fed rate (FED), crude oil price (OIL), broad money (M2), and industrial production growth (IP). 


\subsection{Model Development}

The variable used as a measure of stability was the z-score, which has been previously employed by many researchers. The banking sector will bear the cost of bankruptcy and crises if the total loan is higher than total assets (Mishkin, 2011). Meanwhile, the z-score formula itself is a function of total equity / total assets plus the average return on assets (ROA), divided by the standard deviation of ROA. The equation is as follows (Čihák \& Hesse, 2008):

$$
\boldsymbol{Z}=(\boldsymbol{k}+\boldsymbol{\mu}) / \boldsymbol{\sigma}
$$

In Boyd, De Nicoló and Jalal (2009), the z-score is the sum of ROA and equity to assets (EA), divided by the standard deviation of ROA. This equation is as follows:

$$
Z=(R O A+\mathbf{E A}) / \boldsymbol{\sigma} \mathbf{R O A}
$$

Three equation models were employed in this study, for Indonesian, Malaysian, and Pakistani Islamic banking. The general model equations are as follows:

Model 1: Indonesia

$$
\begin{aligned}
Z-\text { scoreId }_{t} & =A_{0}+A_{1} \text { CAR }_{t-i}+A_{2} C R_{t-j}+A_{3} N P F_{t-k}+A_{4} F D R_{t-1} \\
& +A_{5} E X C_{t-m}+A_{6} D e b t_{t-n}+A_{7} I N F_{t-o}+A_{8} I R_{t-p} \\
& +A_{9} F E D_{t-q}+A_{10} O I L_{t-r}+A_{11} M 2_{t-s}+A_{12} I P_{t-t}+\varepsilon t
\end{aligned}
$$

Model 2: Malaysia

$$
\begin{aligned}
Z-\text { score } M Y_{t} & =A_{0}+A_{1} C A R_{t-i}+A_{2} C R_{t-j}+A_{3} N P F_{t-k}+A_{4} F D R_{t-1} \\
& +A_{5} E X C_{t-m}+A_{6} D e b t_{t-n}+A_{7} I N F_{t-o}+A_{8} I R_{t-p} \\
& +A_{9} F E D_{t-q}+A_{10} O I L_{t-r}+A_{11} M 2_{t-s}+A_{12} I P_{t-t}+\varepsilon t
\end{aligned}
$$

Model 3: Pakistan

$$
\begin{aligned}
Z-\text { scorePK }_{t} & =A_{0}+A_{1} C A R_{t-i}+A_{2} C R_{t-j}+A_{3} N P F_{t-k}+A_{4} F D R_{t-1} \\
& +A_{5} E X C_{t-m}+A_{6} D e b t_{t-n}+A_{7} I N F_{t-o}+A_{8} I R_{t-p} \\
& +A_{9} F E D_{t-q}+A_{10} O I L_{t-r}+A_{11} M 2_{t-s}+A_{12} I P_{t-t}+\varepsilon t
\end{aligned}
$$

\subsection{Method}

The z-score (yt) was the indicator used to measure banking stability, and the method used for regime-switching was MS-VAR (Markov switching-vector auto regression) as this method accommodates the multivariate variables and linear time series with constant parameters (Krolzig, 1997).

The Markov switching model is the same as other regime-switching models in that it processes the observed time-series data $y_{t}=\left(y_{1 t^{\prime}}, \ldots \ldots, y_{k t}\right)$ with variable and constant time parameters when processed using unobservable regime variables $s_{t} \in\{1, \ldots, m\}$. (Krolzig, 1997): 


$$
\begin{gathered}
y_{t}-\mu\left(s_{t}\right)=A_{1}\left(s_{t}\right)\left(y_{t-1}-\mu\left(s_{t-1}\right)\right)+\cdots \\
+A_{p}\left(s_{t}\right)\left(y_{t-p}-\mu\left(s_{t-p}\right)\right)+u_{t}
\end{gathered}
$$

where $u_{t}$ is the Gaussian error condition of $s_{t}: u_{t} \mid s_{t} \sim N I D\left(0, \Sigma_{(s t)}\right)$. The $p$ notation is an M-state Markov switching vector autoregressive model of the dimension $\mathrm{K}$ time series, which shows MS (M) - VAR (p). In addition, the parameters of the shift matrix function $\mu, A_{1}\left(s_{t}\right)+\cdots+A_{p}\left(s_{t}\right)$ and $\Sigma\left(s_{t}\right)$ describe the dependent variable of the parameters $\operatorname{VAR} \mu, A_{1}, \ldots, A_{p}$ and $\Sigma$ for the regime variable $\left(s_{t}\right)$ as follows:

$$
\boldsymbol{\mu}\left(\boldsymbol{s}_{\boldsymbol{t}}\right)=\left\{\begin{array}{l}
\boldsymbol{\mu}_{1}=\left(\boldsymbol{\mu}_{11}, \ldots \ldots, \boldsymbol{\mu}_{K 1}\right)^{\prime} \text { if } \boldsymbol{s}_{\boldsymbol{t}}=1 \\
\vdots \\
\boldsymbol{\mu}_{M}=\left(\boldsymbol{\mu}_{1 M}, \ldots \ldots, \boldsymbol{\mu}_{K M}\right)^{\prime} \text { if } \boldsymbol{s}_{\boldsymbol{t}}=M
\end{array}\right.
$$

In all the MS-VAR specifications, it is assumed that the unobserved state $s_{t}$ follows a first-order Markov chain process, which explains that the current regime $s_{t}$ depends only on the regime of one previous period $s_{t-1}$

$$
p_{i j}=\operatorname{Pr}\left(s_{t}=j \mid s_{t-1}=i\right), \sum_{j=1}^{M} p_{i j}=1 \quad \forall i, j \epsilon\{1, \ldots, M\}
$$

This is what makes the Markov switching process irreducible and ergonomic.

The second model is one with a change in intercept that depends on the $s_{t}$. A regime where there is a one-time jump after the regime change process assumes that the mean changes smoothly to a new level. The equation is as follows:

$$
y_{t}=v\left(s_{t}\right)+A_{1}\left(s_{t}\right) y_{t-1}+\cdots+A_{p}\left(s_{t}\right) y_{t-p}+u_{t}, \quad u_{t} \mid s_{t} \sim N\left(0, \Sigma\left(s_{t}\right)\right.
$$

The adjustment equation for the mean (6) with intercept adjustment (9) has a difference. The permanent regime shift in the mean $s_{t}$ causes a direct jump from the observed time series vector to a new level, while the $s_{t}$ intercept is identical to the shock equivalent to the white noise series $u_{t}$.

There are several specifications of the MS-VAR model in modeling time series against regime change. The notation commonly used for the MS-VAR model specification indicating which variables change with regime change is as follows:

M Markov-switching mean

I Markov-switching intercept

A Markov-switching autoregression parameter

H Markov-switching heteroscedasticity

The MS-VAR model is very flexible and allows heteroscedastic, shifting, trend reversal, and forecasts to be conducted in a non-linear manner. Moreover, the model can be extended for cointegration purposes (Krolzig, 1996). In business cycle analysis, the focus of the model used is the mean MSM (M) -VAR (p) model 
and the MSI (M) -VAR (p) intercept model, because these two models will create a regime of periods of expansion, contraction or even stagnation.

\subsubsection{Function of Regime Shifting}

In this section, we define the variable shift more clearly by formulating the system with a single equation by introducing dummy or more proper indicators (Krolzig, 1997):

$$
\boldsymbol{I}\left(S_{t}=\boldsymbol{\mu}\right)=\left\{\begin{array}{c}
1 \text { if } s_{t}=\mu \\
0 \text { otherwise }
\end{array}\right.
$$

where $\boldsymbol{\mu}=1, \ldots, M$. There are useful to collaborate the information about the realisation of the Markov chain in the vector $\varepsilon_{t}$ as

$$
\varepsilon_{t}=\left[\begin{array}{c}
I\left(S_{t}=1\right) \\
\vdots \\
I\left(S_{t}=\mu\right)
\end{array}\right]
$$

$\varepsilon_{t}$ denotes the unobserved variables; if $\varepsilon_{t}$ consists of the binary variables, then the equation becomes:

$$
E\left(\varepsilon_{t}\right)=\left[\begin{array}{c}
P_{r}\left(S_{t}=1\right) \\
\vdots \\
P_{r}\left(S_{t}=\mu\right)
\end{array}\right]=\left[\begin{array}{c}
P_{r}\left(\varepsilon_{t}=l_{1}\right) \\
\vdots \\
P_{r}\left(\varepsilon_{t}=l_{M}\right)
\end{array}\right]
$$

where $l_{M}$ is $\mathrm{m}$-th column of the identity matrix, $E\left(\varepsilon_{t}\right)$ is a conditional expectation, representing the probability distribution of $S_{t}$.

\section{RESULTS AND ANALYSIS}

\subsection{Preliminary Tests}

\subsubsection{Heteroscedasticity Test}

The heteroscedasticity test results show that the Indonesian equation model is not significant, as evidenced by the Prob F-Stat value of $0.21>0.05$, which means the null hypothesis is rejected, which states that it is heteroscedastic in the data. Furthermore, in the Malaysian equation model the Prob F-Stat value is 0.61>0.05, meaning that the data is homoscedastic, and there is no heteroscedasticity. Finally, in the Pakistani equation model the Prob F-stat value of $0.00<0.05$ means that this equation accepts the null hypothesis, which states that there is heteroscedasticity in the equation model. 
Table 1.

Heteroscedasticity Test

\begin{tabular}{lcc}
\hline Country & F-Statistic & Prob F-Statistic \\
\hline Indonesia & 1.67 & 0.21 \\
Malaysia & 0.84 & 0.61 \\
Pakistan & 4.16 & $0.00^{*}$ \\
\hline
\end{tabular}

Source: Authors' findings (2020)

\subsubsection{Optimum Lag}

The optimum lag test results show that in the Indonesian equation model, the smallest AIC, SC, and HQ values are at lag 3, meaning that this is where the optimum lag is. As for the Malaysian model, the AIC and HQ values are at lag 3, and the SC values are at lag 2, so the optimum lag of the Malaysian model is at lag 3. The Pakistani model's SC and HQ values are at lag 1, but the AIC value is at optimum lag 3, so in this case the optimum lag is lag 1.

Table 2

Optimum Lag

\begin{tabular}{lcccc}
\hline Country & AIC & SC & HQ & Lag \\
\hline Indonesia & $6.19^{* * *}$ & $6.97^{* * *}$ & $6.26^{* * *}$ & 3 \\
Malaysia & $2.44^{* * *}$ & $2.76^{* *}$ & $2.58^{* * *}$ & 2,3 \\
Pakistan & $1.03^{* * *}$ & $1.32^{*}$ & $1.16^{*}$ & 1,3 \\
\hline
\end{tabular}

Source: Authors' findings (2020)

Note:: ${ }^{* * *}=\operatorname{lag} 3{ }^{* *}=\operatorname{lag} 2,{ }^{*}=\operatorname{lag} 1$

\subsubsection{Log-Likelihood}

As can be seen in Table 3, the two MS-VAR models for Indonesia and Malaysia do not contain heteroscedasticity, while that for Pakistan also has two but accommodates heteroscedasticity, namely MSIH and MSIAH. The log-likelihood test is intended to find the goodness of fit in a model; the higher the likelihood number, the better the research model will be.

Table 3.

Log-Likelihood

\begin{tabular}{lccc}
\hline Model MS-VAR & Indonesia & Malaysia & Pakistan \\
\hline MSI & 725.56 & 1067.36 & - \\
MSM & 617.79 & 927.29 & - \\
MSIH & - & - & 915.46 \\
MSIAH & - & - & 808.24 \\
\hline
\end{tabular}

Source: Authors' findings (2020) 
The Indonesian log-likelihood for the MSI model is 725.56> and the MSM model is 617.79, which means that the best model to use for the Indonesian equation is MSI. In the Malaysian MS-VAR model, the MSI log-likelihood value is 1067.36> and MSM is 927.29, meaning that the best model for the Malaysian MSVAR equation is MSI. Finally, the MSIH MSIH log-likelihood values of 915.46> and MSIAH 808.24 mean that the best MS-VAR model for Pakistan is MSIH.

\subsubsection{LR Linearity Test}

The results of the LR linearity test show that the chi-square value and the Davies value of the Indonesian, Malaysian and Pakistani equations all show values that are lower than the 0.05 level, meaning that the research data is non-linear between the variables, so the data analysis was conducted using a non-linear regression model such as MS-VAR.

Table 4.

LR Linearity Test

\begin{tabular}{lccc}
\hline Country & Value & Chi-Square & Davies \\
\hline Indonesia & 83.74 & 0.00 & 0.00 \\
Malaysia & 1067.36 & 0.00 & 0.00 \\
Pakistan & 1049.05 & 0.00 & 0.00 \\
\hline
\end{tabular}

Source: Authors' findings (2020)

\subsection{Results}

\subsubsection{Indonesian Model Equation}

\section{a. Matrix of Transition Probabilities}

Table 5 shows a transition from a stable state (regime 1) to an unstable one (regime 2 ), which for the Indonesian model is $6 \%$. In comparison, for the transition from regime 2 to regime 1, it is $3 \%$. These transition values means that Indonesia's transition from a stable regime to an unstable one is greater than that from an unstable regime to a stable one.

Table 5.

Transition Probabilities Matrix of the Indonesian Model

\begin{tabular}{lcc}
\hline & Regime 1 & Regime 2 \\
\hline Regime 1 & 0.94 & 0.06 \\
Regime 2 & 0.03 & 0.97 \\
\hline Source: Authors' findings (2020) & &
\end{tabular}

Source: Authors' findings (2020)

\section{b. Regime Probabilities}

Table 6 shows the duration of the stable and unstable periods in the data modeling cycle, with the results of the Indonesian data model showing that the duration in regime 2 (around 32 months) was more prolonged than in regime 1, which was 
around 18 months, and that the probability level in regime 2 is also greater, at around $64 \%$, compared to $36 \%$ for regime 1 .

Table 6.

Regime Probabilities of the Indonesian Model

\begin{tabular}{lccc}
\hline & No. Obs & Prob. & Duration \\
\hline Regime 1 & 55 & 0.36 & 18 \\
Regime 2 & 98 & 0.64 & 32 \\
\hline
\end{tabular}

Source: Authors' findings (2020)

\section{c. Coefficients and t-values}

The significance value is seen from the comparison between the t-value and the $t$-table; the $t$-value must be smaller than the $t$-table value. With 156 data per variable, the $t$-table value is 1.96 . Observing the $t$-value of the Indonesian equation model, there are five significant variables, namely the z-scoreId, CR, INF, M2, and IR.

Table 7.

Variable Coefficients of the Indonesian Model

\begin{tabular}{lccc}
\hline Variable & Coefficient & t-value & Significance \\
\hline ZscoreId & 11.16 & 1.38 & Significant \\
CAR & -42.82 & -3.60 & Not significant \\
CR & -2.41 & -1.02 & Significant \\
NPF & 10.72 & 2.14 & Not significant \\
FDR & -79.54 & -1.99 & Not significant \\
EXC & -0.81 & -2.58 & Not significant \\
DEBT & 0.39 & 2.37 & Not significant \\
INF & 8.16 & 1.17 & Significant \\
M2 & 0.08 & 0.51 & Significant \\
IR & -4.44 & -1.93 & Significant \\
OIL & 4.05 & 3.76 & Not significant \\
FED & 14.12 & 4.27 & Not significant \\
\hline
\end{tabular}

Source: Authors' findings (2020)

\section{d. Regime Classification}

Figure 4 shows economic cycles for the Indonesian equation model during the periods January 2008 - March 2008, October 2008 - September 2010, and March 2011 - June 2013, when the country was in a state of tranquillity or stability. Meanwhile, April 2007 - December 2007, April 2008 - September 2008, October 2010 - February 2011, and July 2013 - December 2019 were unstable periods for Indonesia. 


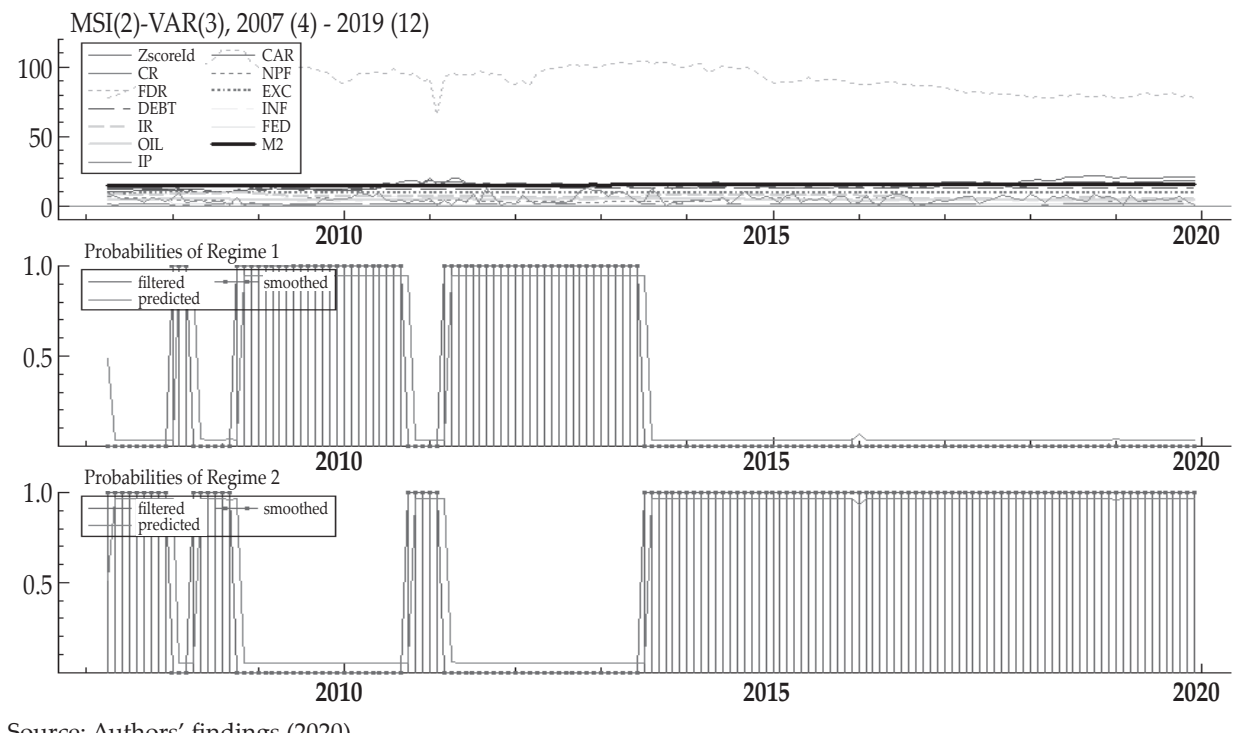

Source: Authors' findings (2020)

Figure 4.

Regime Classification of Indonesian Banking

\subsubsection{Malaysian Model Equation}

\section{a. Matrix of Transition Probabilities}

Table 8 shows that the transition from regime 1 (stable) to regime 2 (unstable) for the Malaysian model was 3\%, the same as for that from regime 2 to regime 1 . This indicates that the country's transition from a stable regime to an unstable one was equal to that from an unstable regime to a stable one.

Table 8.

Transition Probabilities Matrix of the Malaysian Model

\begin{tabular}{lcc}
\hline & Regime 1 & Regime 2 \\
\hline Regime 1 & 0.97 & 0.03 \\
Regime 2 & 0.03 & 0.97 \\
\hline
\end{tabular}

Source: Authors' findings (2020)

\section{b. Regime Probabilities}

Table 9 shows the stable and unstable periods in the data modeling cycle in the Malaysian model are around 30 months, and that the probability number between regimes the same regime 2 is around $50 \%$. 
Table 9.

Regime Probabilities of the Malaysian Model

\begin{tabular}{lccc}
\hline & No. Obs & Prob. & Duration \\
\hline Regime 1 & 90 & 0.50 & 30.3 \\
Regime 2 & 63 & 0.50 & 30.6 \\
\hline
\end{tabular}

Source: Authors' findings, 2020

\section{c. Coefficients and $t$-values}

The significance value is seen from the comparison between the $t$-value and the $\mathrm{t}$-table; the $\mathrm{t}$-value must be smaller than the $\mathrm{t}$-table value. For 156 data per variable, the $t$-table value is 1.96. If one observes the $t$-value of the Malaysian equation model, there are nine significant variables, namely CR, NPF, FDR, EXC, DEBT, INF, M2, IR, and OIL.

Table 10.

Variable Coefficients of the Malaysian Model

\begin{tabular}{lccc}
\hline Variable & Coefficient & t-value & Significance \\
\hline ZscoreMy & 64.33 & 4.32 & Not significant \\
CAR & -11.93 & -1.97 & Not significant \\
CR & -1.85 & -0.63 & Significant \\
NPF & 3.11 & 1.05 & Significant \\
FDR & -39.11 & -1.48 & Significant \\
EXC & -0.37 & -0.88 & Significant \\
DEBT & -3.96 & -1.32 & Significant \\
INF & 2.47 & 0.23 & Significant \\
M2 & 0.29 & 1.58 & Significant \\
IR & -2.06 & -1.26 & Significant \\
OIL & -0.47 & -0.29 & Significant \\
FED & -5.37 & -2.62 & Not significant \\
\hline
\end{tabular}

Source: Authors' findings, 2020

\section{d. Regime Classification}

Figure 5 shows the existence of an economic cycle for the Malaysian equation model. During the periods April 2007 - December 2007, May 2008 - July 2008, and September 2008 - April 2015, the country was experiencing tranquillity or stability. However, in January 2008 - April 2008, August 2008 - October 2008, and May 2015 - December 2019, Malaysia was in an unstable state. 

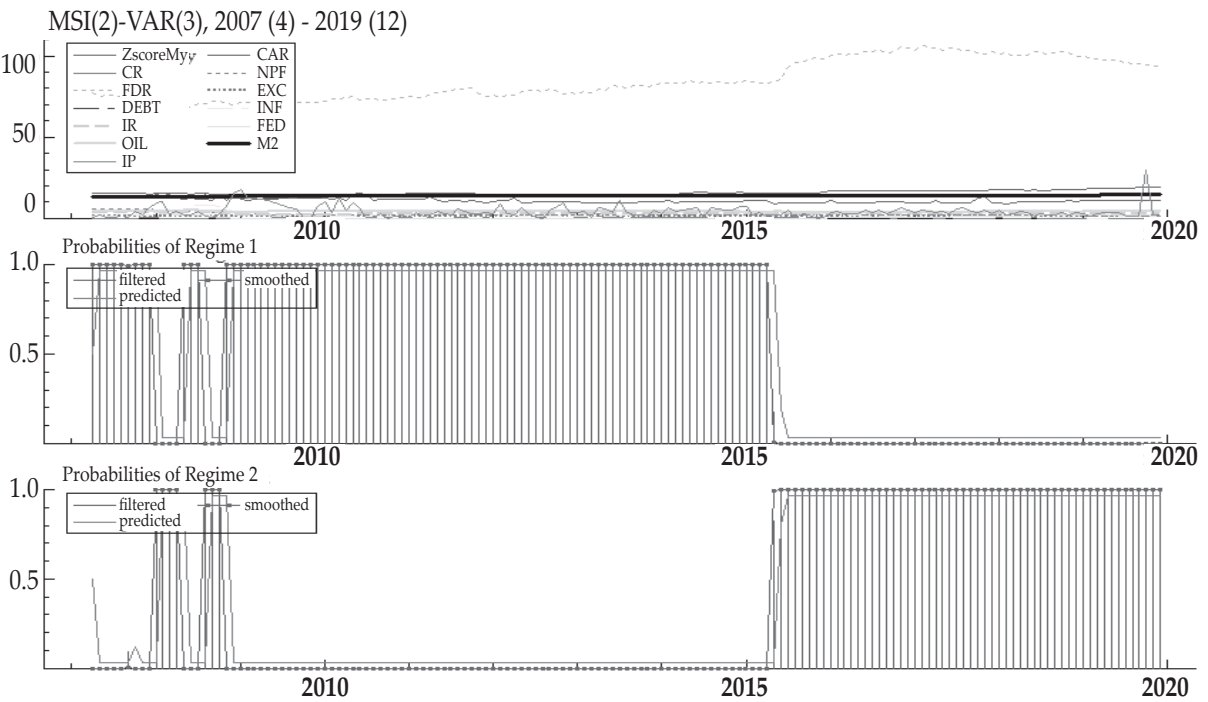

Source: Authors' findings (2020)

Figure 5.

Regime Classification of Malaysian Banking

\subsubsection{Pakistani Equation Model}

\section{a. Matrix of Transition Probabilities}

Table 11 shows that the transition from regime 1 (stable) to regime 2 (unstable) for the Pakistani model was $20 \%$, while that from regime 2 to regime 1 was $39 \%$. These values mean that the country's transition from an unstable regime to a stable one was greater than that from a stable regime to an unstable one.

Table 11.

Transition Probabilities Matrix of the Pakistani Model

\begin{tabular}{lcc}
\hline & Regime 1 & Regime 2 \\
\hline Regime 1 & 0.80 & 0.20 \\
Regime 2 & 0.39 & 0.61 \\
\hline
\end{tabular}

Source: Authors' findings (2020)

\section{b. Regime Probabilities}

Table 12 shows the duration of the stable and unstable periods in the data modeling cycle of the Pakistani data model. Regime 1 is longer than regime 2, at around 5 months compared to 3 months, and the probability rate in regime 1 is greater, at around $66 \%$ compared to $34 \%$ for regime 2 . 
Table 12.

Regime Probabilities of the Pakistani Model

\begin{tabular}{lccc}
\hline & No Obs & Prob. & Duration \\
\hline Regime 1 & 103 & 0.66 & 5 \\
Regime 2 & 52 & 0.34 & 3 \\
\hline
\end{tabular}

Source: Authors' findings (2020)

\section{c. Coefficients and t-values}

The significance value is seen from the comparison between the t-value and the $\mathrm{t}$-table; the $\mathrm{t}$-value must be smaller than the $\mathrm{t}$-table value. For 156 data per variable, the $t$-table value is 1.96. Observing the $t$-value of the Pakistani equation model, there are two significant variables, namely CR and OIL.

Table 13.

Variable Coefficients of the Pakistani Model

\begin{tabular}{lccc}
\hline Variable & Coefficient & t-value & Significance \\
\hline ZscorePk & -12.29 & -105.06 & Not significant \\
CAR & 8.19 & 147.50 & Not significant \\
CR & -1.04 & -1.42 & Significant \\
NPF & -3.16 & -40.86 & Not significant \\
FDR & 134.95 & 231.44 & Not significant \\
EXC & 0.18 & 2.31 & Not significant \\
DEBT & 0.23 & 2.98 & Not significant \\
INF & 44.94 & 287.03 & Not significant \\
M2 & -1.21 & -2.65 & Not significant \\
IR & 2.01 & 27.55 & Not significant \\
OIL & -0.34 & -0.19 & Significant \\
FED & -2.78 & -2.81 & Not significant \\
\hline
\end{tabular}

Source: Authors' findings (2020)

\section{d. Regime Classification}

Figure 6 shows the existence of an economic cycle for the Pakistan equation model. During the periods March 2007, May - August 2008, December 2008 - January 2009, December 2019 - February 2010, June - August 2010, September - December 2011, August - October 2011, December 2011 - August 2012, October - November 2013, January - February 2014, April 2014 - September 2016, February - November 2017, January - February 2018, May 2018, July 2018, September 2018, November December 2018, February - June 2019, and August - September 2019, the country was in periods of tranquillity or stability. On the other hand, during the periods February 2007, April 2007, September 2007 - November 2008, February - November 2009, March - May 2010, September - October 2010, March - April 2011, July 2011, September 2012, December 2013, March 2014, December 201 6- January 2017, December 2017, March - April 2018, June 2018, August 2018, October 2018, January 2019, July 2019, and October - December 2019, Pakistan was experiencing unstable periods. 


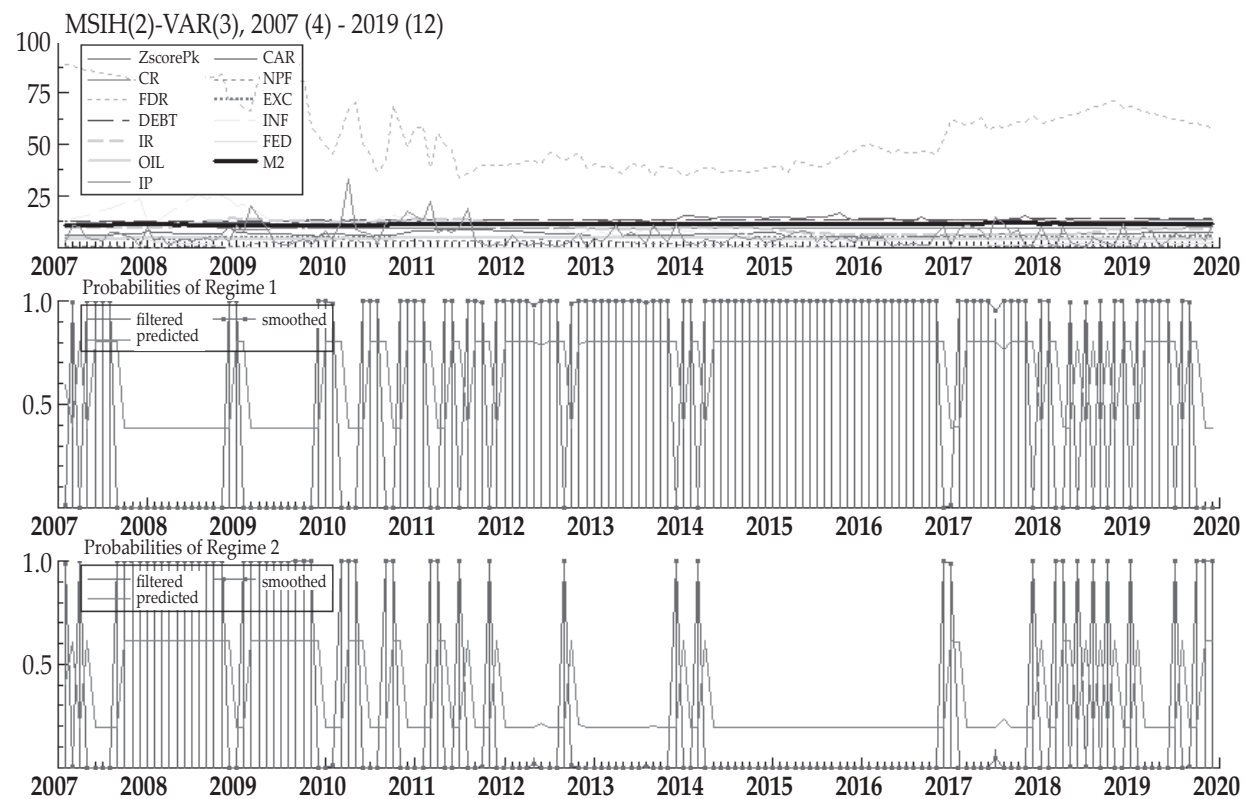

Source: Authors' findings, 2020

Figure 6.

Regime Classification of Pakistani Banking

\subsection{Analysis}

\subsubsection{Z-score Comparison}

The z-scores is commonly used as a proxy of banking stability as it has an inverse relationship with banks' bankruptcy. Many researchers have utilised z-scores to measure banking stability, as previously discussed. Therefore, z-scores are also employed in this study to measure Islamic bank stability in Indonesia, Malaysia, and Pakistan.

The z-score data processing results show that Indonesian Islamic banking has the highest value, at 14.35, followed by Malaysian Islamic banking, with an average z-score of 11.16. The lowest average z-score was obtained by Pakistani Islamic banking. Figure 7 shows a comparison of the average z-scores of the three countries. 


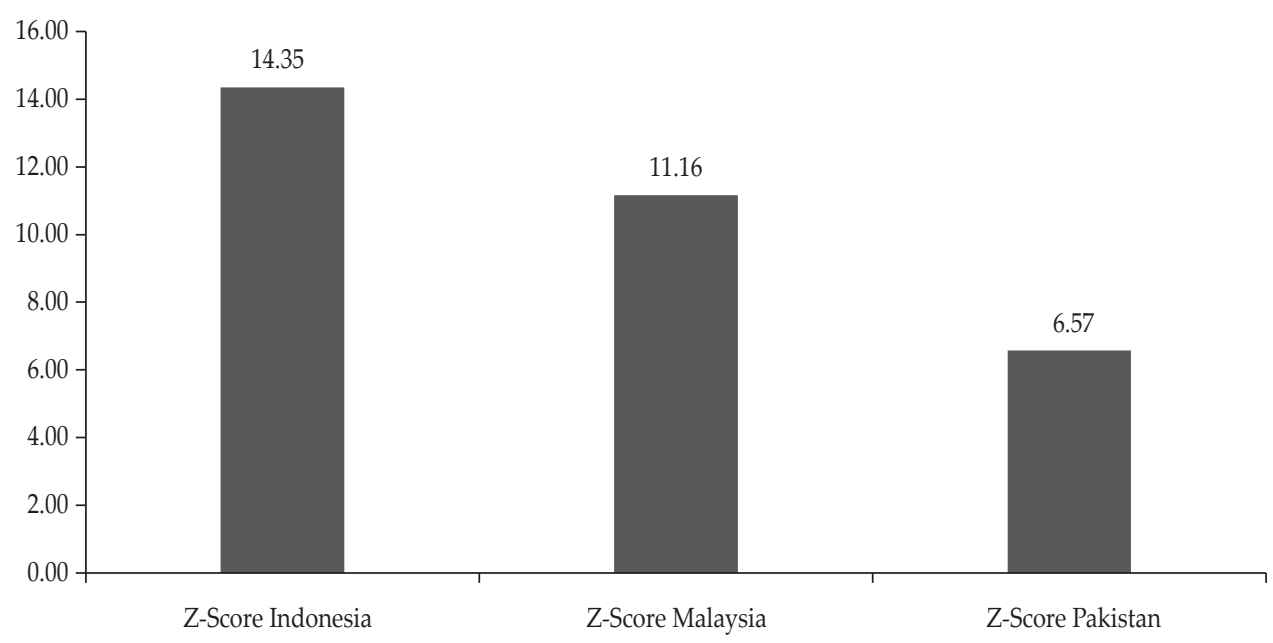

Source: Authors' findings (2020)

Figure 7.

Average z-scores of Indonesia, Malaysia, and Pakistan, 2007-2019

According to Čihák and Hesse (2008), higher z-score values imply a lower risk of bankruptcy or insolvency. Bouvatier, Lepetit, Rehault and Strobel (2017) also demonstrate that the best measure of banking stability with the multivariate model is z-score-based ROA using the current value of the capital asset ratio. Li et al. (2016) measured bank risk in New Zealand and Australia with the z-score indicator and proved that it was effective in capturing bank and systemic risk.

Based on the results, Pakistani Islamic banking needs to improve the return on assets from all its banking business processes to achieve stable Islamic banking and avoid insolvency. In addition, Malaysian Islamic banking should pay attention to the measurement of z-scores, especially as the country is the world centre of the Islamic economy. Finally, Indonesia should not be negligent towards Islamic banking stability and maintain z-score performance. It is presumed that the greater the age of Islamic banking, the slower its growth; in Pakistan and Malaysia it was established in the 1980s, while in Indonesia it was established in the 1990s (Rammal \& Parker, 2013; Kunhibava, 2012; Dwi Sari, 2016).

\subsubsection{Analysis of Indonesian Variables}

The Indonesian model (Table 7) shows that CR's significant microeconomic variable negatively impacts Islamic banking in the country. This indicates that an increase in CR of $1 \%$ will reduce Islamic banking stability in Indonesia by $2.14 \%$. This result is contrary to the theory, which proposes that an increase in CR means the liquidity assets of Islamic banking wil also increase, thus reducing the potential risk of instability. However, a large amount of liquidity will disrupt banks' business cycle as they have to set a percentage of liquidity reserves (Bathaluddin et al., 2012; Wagner, 2007). 
In addition, the significant macroeconomic variables are INF, M2, and IR. Inflation has a significant and positive impact on Islamic banking in Indonesia; an increase in inflation of $1 \%$ will also increase Islamic banking stability by $8.16 \%$. This result is a paradox, as high inflation will normally lead to instability in the economy. Nevertheless, an increase in inflation coupled with real output also will increase people's income, which means it is true that Islamic banking is more focused on the real sector than on the monetary sector (Ryu \& Yu, 2020; Tan, 2016; Tan \& Floros, 2012).

Furthermore, money supply has a significant and positive impact, with an increase in money supply of $1 \%$ increasing the stability of Islamic banking in Indonesia by $0.08 \%$. With regard to recession, money supply will be increased and reduced during high inflation by raising the interest rate (Helhel, 2014; Obeidat et al., 2013).

Finally, the interest rate has a significant and negative impact if it increased by $1 \%$. It will also reduce the stability of Islamic banking. High interest rates increase the number of non-performing loans, thereby disrupting the business cycle and Islamic banking stability (Khan \& Sattar, 2014).

\subsubsection{Analysis of Malaysian Variables}

The Malaysian model (table 10) shows that CR has a significant and negative impact on Malaysian Islamic banking. This result is the same as for the Indonesian model. However, it is different at the level of the influence; an increase in liquidity of $1 \%$ will reduce the stability of Islamic banking in Malaysia by $1.85 \%$. This is possible because of the provisions of banks' liquidity storage limit and is in line with previous results obtained by Bathaluddin et al. (2012) and Wagner (2007).

In addition, NPF has a significant and positive impact on Islamic banking in Malaysia, which is contrary to the theory. An increase in NPF of $1 \%$ will also increase the stability of Islamic banking. According to Zulfiah and Susilowibowo (2014), NPF will not disturb overall banking stability because the allowance for earning assets losses caused by NPF can still manage non-performing loans. Furthermore, the previous study Buchory (2016) obtained the same results.

The FDR variable has a significant and negative impact on Islamic banking in Malaysia; an increase in FDR of $1 \%$ will reduce stability by $39.11 \%$. This result shows that large-scale financing that exceeds deposit funds will cause liquidity problems, eventually leading to bankruptcy (Park et al., 2015).

The EXC variable has a negative and significant impact on Islamic banking in the country. An increase in EXC of $1 \%$ will reduce stability by around $0.37 \%$. The depreciation of the Malaysian ringgit will impact maturing debt paid more than the previous price (Priti, 2016; He et al., 2014).

The DEBT variable also has a negative and significant impact. An increase in EXC of $1 \%$ will reduce stability by around $3.96 \%$. Substantial foreign debt will burden the government's spending budget and risk default (Ryu \& Yu, 2020).

The next variable is INF, which has a significant and positive impact on Islamic banking in Malaysia. An increase in inflation of $1 \%$ will increase stability by $2.47 \%$. This result is a paradox where the high inflation will lead to the instability of the economy. Nevertheless, an increase in inflation coupled with real output also will 
increase people's income, which means it is true that Islamic banking is more focused on the real sector than the monetary sector (Ryu \& Yu, 2020; Tan, 2016; Tan \& Floros, 2012).

The M2 variable shows significant results and a positive and significant impact, which means thatr an increase in M2 of 1\% will increase Islamic banking stability by $0.29 \%$. In theory, an increase in money supply during a recession will increase spending and cause inflation to stabilise, thus beginning economic stability in a new equilibrium (Helhel, 2014; Obeidat et al., 2013).

The significant variable in relation to Islamic banking in Malaysia is IR, which has a negative and significant impact, meaning that an increase in interest rates of $1 \%$ will reduce banking stability by $4.44 \%$. Higher interest rates will lead to bad debt and increase the risk of failure, wich will disrupt Islamic banking stability (Khan \& Sattar, 2014).

Finally, the OIL variable has a significant and negative impact on Islamic banking in Malaysia. An increase of $1 \%$ will reduce its stability by $0.47 \%$. The volatility of crude oil prices will impact the price stability of goods and services. As financial intermediaries, banks will also be regularly affected (Lee \& Lee, 2019).

\subsubsection{Analysis of Pakistani Variables}

The Pakistani model (Table 13) shows only two significant variables related to Islamic banking stability in Pakistan, CR and OIL. CR has a significant and negative impact on Islamic banking in the country; an increase in CR by $1 \%$ will reduce stability by $1.04 \%$. CR in the banking industry means that liquidity assets have a determined amount, so excess liquidity will make it difficult for banks to distribute it. This will affect the continuity of the banking process (Bathaluddin et al., 2012; Wagner, 2007).

Second, OIL has a significant and negative impact; an increase of $1 \%$ will reduce the stability of Islamic banking in Pakistan by $0.47 \%$. The volatility of crude oil prices will affect consumer goods and services, making them unreachable, and leading to massive withdrawals. Banks will experience a lack of liquidity, and bank runs will occurr (Lee \& Lee, 2019).

\section{CONCLUSION AND RECOMMENDATIONS}

\subsection{Conclusion}

From the previous discussions, several conclusions were reached from the formulation of the research problem, namely:

1. Islamic banking stability is an economic and financial cycle; certain periods will be calm and others will experience crises. This is normal, but attention needs to be focused on the duration of instability, because if it is not handled properly, it will worsen the situation and trigger a banking crisis that will become a financial and economic crisis. This is shown in the research results, where the Islamic banks in three countries at the end of the study period were at a level of instability.

2. Based on the z-score values, Islamic banks in Indonesia have a higher score than in the other two countries, indicating that Indonesia has the lowest insolvency level. Overall, from the regression model results with the various variables, 
Malaysia has the best performance. This can be seen from the regime shifting and the shorter duration of the Malaysian crisis. On the other hand, Pakistan still needs to improve its performance so that it can become more stable.

3. From the 12 variables used to study the cyclical instability of the three distinct countries, the most influential variable in Islamic banking in Indonesia was inflation, whereas the financing to deposit ratio was highly significant for all Islamic banking in Malaysia. Finally, Islamic banking in Pakistan was mostly impacted by fluctuations in global oil prices.

\subsection{Recommendations}

From these conclusions, several recommendations are proposed:

1. Policymakers should be more careful in determining the direction of their country's economic policies, as economic conditions have cycles of instability, so solutions are needed to maintain economic indicators stable. Particularly in Indonesia, it is necessary to have government policies that continue to support Islamic banking's increasing market share. Islamic banking assets need to be increased within the framework of strengthening banking stability in general.

2. All Islamic banks need to understand the volatility of economic and financial conditions within their own country and overseas, especially those related to variables that affect instability. The most frequently used indicator is the z-score, which describes bank crises, therefore Islamic banks should be aware of the return on assets (ROA) variable, which is the basis for its calculations. The two other countries must raise the value of their ROA and learn from Indonesia, which has the highest z-score value. However, Indonesia and Pakistan, as well as Malaysia, should improve the performance of the independent variables, with mostly variables regressed were more stable than in the other two countries.

3. For bankers, the results could be used as a reference for improving business strategy in the face of unstable economic conditions. To maintain banking system stability, Islamic banks need to be more careful and refine their strategies in dealing with uncertain financial conditions, both in terms of strengthening capital and credit or financing, especially in this VUCA condition.

4. In further research, it is recommended that more research indicators be used, the research period, and the country of research objects, in order to be more beneficial for the public. Robustness testing also needs to be conducted with other methods that are more precise and robust so that the research results are more robust and can be applied to various conditions and different loci.

5. The implication of cross-country analysis is a system that can be adopted from Islamic banking with the highest level of stability. In addition, each country can analyse whether the systems and policies implemented there can also be applied in other countries. As the z-score is used as a proxy indicator of banking stability, the three countries in this study must notice and maintain to the return on assets (ROA) in the domestic Islamic banking industry as an area of improvement. 


\section{REFERENCES}

Agénor, P., \& Pereira, L. A. (2014). Financial spillovers, spillbacks, and the scope for international macroprudential policy coordination. Journal of Financial and Quantitative Analysis, 49(June 2014), 575-598. https://www.bis.org/publ/bppdf/ bispap97.htm.

Akram Laldin, M. (2008). Islamic financial system: The Malaysian experience and the way forward. Humanomics, 24(3), 217-238. https:/doi. org/10.1108/08288660810899377.

Allen, W. A., \& Wood, G. (2006). Defining and achieving financial stability. Journal of Financial Stability, 2(2), 152-172. https://doi.org/10.1016/j.jfs.2005.10.001.

Alqahtani, F., \& Mayes, D. G. (2018). Financial stability of Islamic banking and the global financial crisis: Evidence from the Gulf Cooperation Council. Economic Systems, 42(2), 346-360. https://doi.org/10.1016/j.ecosys.2017.09.001.

Andries, A. M., \& Galasan, E. (2020). Measuring financial contagion and spillover effects with a state-dependent sensitivity value-at-risk model. Risks, 8(1), 1-20. https://doi.org/10.3390/risks8010005.

Ascarya (2009). Forgotten root causes of the crisis. IPEBI Serial Roundtable Discussion on "Krisis Keuangan Global Dan Outlook Perekonomian Indonesia 2009: Tantangan Bagi Pegawai Bank Indonesia," January 28, 2009., Januari, 1-8.

Ascarya, A. (2010). Lessons learned from repeated financial crises: An Islamic economic perspective. Bulletin of Monetary Economics and Banking, 12(1), 27-74. https://doi.org/10.21098/bemp.v12i1.466.

Bathaluddin, M. B., Adhi, P. N. M., \& Wibowo, W. A. (2012). The impact of excess liquidity on monetary policy. Bulletin of Monetary Economics and Banking, 14(January), 245-267. https://doi.org/10.21098/bemp.v14i3.404.

Bossone, B. (2001). Circuit theory of banking and finance. Journal of Banking and Finance, 25(5), 857-890. https://doi.org/10.1016/S0378-4266(00)00100-X.

Bouvatier, V., Lepetit, L., Rehault, P. N., \& Strobel, F. (2017). Bank insolvency risk and z-score measures: Caveats and best practice. SSRN Electronic Journal (July 18), 1-36. https://doi.org/10.2139/ssrn.2892672.

Boyd, J. H., De Nicoló, G., \& Jalal, A. M. (2009). Bank competition, risk and asset allocations. IMF Working Papers, 09(143), 1-36. https://doi. org/10.5089/9781451872903.001.

Buchory, H. A. (2016). Determinants of banking profitability in Indonesian regional development bank. Actual Problems of Economics, 177(3), 308-318.

Central Bank of Indonesia (2020). What is financial stability? Financial System Stability, November. Retrieved from https://www.bi.go.id/en/ssk/ssk/ikhtisar/ definisi/Contents/Default.aspx.

Central Bank of Malaysia (2020a). Islamic banks in Malaysia. Financial stability, November. Retrieved from https://www.bnm.gov.my/index. php?ch=li\&cat=islamic\&type=IB\&lang=en.

Central Bank of Malaysia (2020b). What is financial stability? Central Bank of Malaysia, November. Retrieved from https://www.bnm.gov.my/index. php?ch=fs\&pg=fs_ovr_what\&ac=112\#: :text=The financial system plays a,promoting economic growth and development.

Cihák, M. (2006). How do central banks writeon financial stability? IMF Working Papers, 06(163), 1. https://doi.org/10.5089/9781451864236.001. 
Čihák, M., \& Hesse, H. (2008). Islamic Banks and Financial Stability: An Empirical Analysis. IMF Working Paper, 08(16).

Dwi Sari, M. (2016). History of Islamic bank in Indonesia: Issues behind its establishment. International Journal of Finance and Banking Research, 2(5), 178184. https://doi.org/10.11648/j.ijfbr.20160205.13.

EIA (2020). Spot prices for crude oil and petroleum products. US Energy Information Administration, 2020. Retrieved from https://www.eia.gov/dnav/pet/hist/ LeafHandler.ashx? $\mathrm{n}=$ pet\&s $=\mathrm{rbrte} \& \mathrm{f}=\mathrm{w}$.

Fernández, A. I., González, F., \& Suárez, N. (2016). Banking stability, competition, and economic volatility. Journal of Financial Stability, 22(February 2016), 101120. https://doi.org/10.1016/j.jfs.2016.01.005.

Financial Services Authority of Indonesia (2020). Monthly Report of Sharia Banking Statistics of Indonesia. Statistik Perbankan Syariah, Agustus.

Gorton, G., \& Winton, A. (2003). Financial intermediation. In G. M. Constantinides , M. Harris, \& R. M. Stulz (Eds.), Handbook of the Economics of Finance (Vol. 1, Issue SUPPL. PART A, pp. 431-552). Elsevier Masson SAS. https://doi. org/10.1016/S1574-0102(03)01012-4.

Hassan, M. K., \& Aliyu, S. (2018). A contemporary survey of islamic banking literature. Journal of Financial Stability, 34(February 2018), 12-43. https://doi. org/10.1016/j.jfs.2017.11.006.

He, L. T., Fayman, A., \& Casey, K. M. (2014). Bank profitability: The impact of foreign currency fluctuations. Journal of Applied Business and Economics, 16(2), 98-104.

Helhel, Y. (2014). Evaluating the performance of the commercial banks in Georgia. Research Journal of Finance and Accounting, 5(22), 146-157. Retrieved from https://www.researchgate.net/profile/Yesim_Helhel/publication/270338120_ Evaluating_The_Performance_of_the_Commercial_Banks_In_Georgia/ links/54a91b5f0cf257a6360bf204.pdf.

Houben, A., Kakes, J., \& Schinasi, G. (2004). Toward a framework for safeguarding financial stability. IMF Working Papers, 04(101). Retrieved from https://doi. org/10.5089/9781451852547.001.

İdikut Özpençe, A. (2017). Economic stability and growth: The case of Turkey. Research in Applied Economics, 9(3), 41-63. https://doi.org/10.5296/rae.v9i4.12041.

IFSB (2020). Islamic financial services industry stability report 2020. Islamic Financial Services Board, Dec, 1-54. Retrieved from www.cbb.gov.bh.

Illing, M., \& Liu, Y. (2003). An index of financial stress for Sweden. Working Paper Bank of Canada, 14(6), 49-67.

Issing, O. (2003). Monetary and financial stability - is there a trade-off ? Conference on "Monetary Stability, Financial Stability and the Business Cycle", BIS, March, 28-29.

Khan, W. A., \& Sattar, A. (2014). Impact of interest rate changes on the profitability of four major commercial banks in Pakistan. International Journal of Accounting and Financial Reporting, 4(1), 142-154. https://doi.org/10.5296/ijafr.v4i1.5630.

Krolzig, H. (1996). Statistical analysis of cointegrated VAR processes with Markovian regime shifts. SFB 373 Discussion Papers, 25.

Krolzig, H. (1997). Markov-switching vector autoregressions modelling, stastical inference, and application to business cycle analysis (P. D. W. (Institut fur M. W. 
Fandel, Prof.Dr.G. (Fachbereich Wirtschaftwissenschaften); Trockel (ed.)). Springer-Verlag Berlin Heidelberg. https://doi.org/10.1007/978-3-642-51684-9.

Kunhibava, S. (2012). Islamic banking in Malaysia. International Journal of Legal Information, 40(1-2), 191-201. https://doi.org/10.1017/s0731126500006478.

Laeven, L., \& Valencia, F. (2012). Systemic banking crises database: An update. IMF Working Paper, 12(163).

Lee, C. C., \& Lee, C. C. (2019). Oil price shocks and Chinese banking performance: Do country risks matter? Energy Economics, 77(January 2019), 46-53. https:// doi.org/10.1016/j.eneco.2018.01.010.

Li, X., Tripe, D., \& Malone, C. B. (2016). Measuring bank risk: An exploration of z-score. SSRN Electronic Journal, January. https://doi.org/10.2139/ssrn.2823946.

Matey, J. (2019). Financial performance analysis of distressed banks in Ghana: Exploration of financial ratios and z-score. MPRA Paper, 97095(September), 1-16. https://mpra.ub.uni-muenchen.de/97095/.

Mirakhor, A., \& Krichene, N. (2009). The recent crisis: Lessons for Islamic finance. Journal of Islamic Economics, Banking and Finance, 5(1), 9-58. http://ibtra.com/ pdf/journal/v5_n1_article1.pdf.

Mishkin, F. S. (2011). Over the cliff: From the subprime to the global financial crisis. Journal of Economic Perspectives, 25(1), 49-70. https://doi.org/10.1257/jep.25.1.49.

Mutiah, A., \& Tamanni, L. (2010). Analisis pengaruh monetary policy shock terhadap jumlah deposito perbankan Islam dalam sistem perbankan ganda: Studi kasus Indonesia dan Malaysia [Analysis of the effect of monetary policy shock on the amount of deposits in Islamic banking in a dual banking system: A case study of Indonesia and Malaysia]. Tazkia Islamic Finance and Business Review, 5(1), 21-38.

Nizar, M. A. (2012). The Impact of financial crisis on indonesia's economy. Buletin Ilmiah Litbang Perdagangan, 6(Dec), 189-210. https://mpra.ub.uni-muenchen. de/65601/1/MPRA_paper_65601.pdf.

Nurfalah, I., Rusydiana, A. S., Laila, N., \& Cahyono, E. F. (2018). Early warning to banking crises in the dual financial system in Indonesia: The Markov switching approach. Journal of King Abdul Aziz University, 31(2), 133-156. https:/doi. org/10.4197/Islec.

Obeidat, B. Y., El-Rimawi, S. Y., Masa'deh, R. M. d. T., Maqableh, M. M., \& AlJarrah, I. M. (2013). Evaluating the profitability of the Islamic banks in Jordan. European Journal of Economics, Finance and Administrative Sciences, (56), 27-36.

Ozili, P. K. (2018). Banking stability determinants in Africa. International Journal of Managerial Finance, 14(4), 462-483. https://doi.org/10.1108/IJMF-01-2018-0007.

Park, H., Jun, H., \& Lee, D. (2015). Evaluation on the usefulness of the loan-todeposit ratio regulation - From the macroprudential policy perspective -. Journal of Business Studies Quarterly, 2(3), 74-84.

Powell, R. J. (2017). New perspectives on bank risk in Malaysia. Cogent Economics and Finance, 5(1), 1-15. https://doi.org/10.1080/23322039.2017.1326217.

Priti, V. (2016). The impact of exchange rates and interest rates on bank stock returns: Evidence from U.S banks. Studies in Business and Economics, 11(1), 124-139. https://doi.org/10.1515/sbe-2016-0011.

Rammal, H. G., \& Parker, L. D. (2013). Islamic banking in Pakistan: A history of emergent accountability and regulation. Accounting History, 18(1), 5-29. https:// doi.org/10.1177/1032373212463269. 
Reinhart, C. M., \& Rogoff, K. S. (2013). Financial and sovereign debt crises: Some lessons learned and those forgotten. IMF Working Paper, 13(266). https://doi. org/10.7172/2353-6845.jbfe.2015.2.1.

Ryu, D., \& Yu, J. (2020). Nonlinear effect of subordinated debt changes on bank performance. Finance Research Letters, 38(January 2020), 101496. https://doi. org/10.1016/j.frl.2020.101496.

Schinasi, G. J. (2004). Defining financial stability. IMF Working Papers, 04(187). https://doi.org/10.5089/9781451859546.001.

State Bank of Pakistan (2020a). Financial stability. State Bank of Pakistan, November. https://www.sbp.org.pk/FS/FSA.asp.

State Bank of Pakistan (2020b). Islamic banking bulletin. Islamic Banking Department, April-June. http://www.sbp.org.pk/ibd/Bulletin/Bulletin.asp.

Tan, Y. (2016). The impacts of risk and competition on bank profitability in China. Journal of International Financial Markets, Institutions and Money, 40(January 2016), 85-110. https://doi.org/10.1016/j.intfin.2015.09.003.

Tan, Y., \& Floros, C. (2012). Bank profitability and inflation: The case of China. Journal of Economic Studies, 39(6), 675-696. Retrieved from https://doi. org/10.1108/01443581211274610.

Wagner, W. (2007). The liquidity of bank assets and banking stability. Journal of Banking and Finance, 31(1), 121-139. Retrieved from https://doi.org/10.1016/j. jbankfin.2005.07.019.

Wong, K. K. S., \& Shamsudin, M. N. (2017). Impact of crude oil price, exchange rates and real GDP on Malaysia's food price fluctuations: Symmetric or asymmetric? International Journal of Economics and Management, 11(1), 259-275.

Zahra, S. F., Ascarya, A., \& Huda, N. (2018). Stability measurement of dual banking system in Indonesia: Markov switching approach. Al-Iqtishad: Jurnal Ilmu Ekonomi Syariah, 10(1), 25-52. https://doi.org/10.15408/aiq.v10i1.5867.

Zulfiah, F., \& Susilowibowo, J. (2014). Pengaruh inflasi, BI rate, capital adequacy ratio (car), non performing finance (npf), biaya operasional dan pendapatan operasional (bopo) terhadap profitabilitas bank umum syariah periode 20082012. Jurnal Ilmu Manajemen, 2(3), 759-770. 
This page is intentionally left blank 